\title{
Changes in the mediatization of politics
}

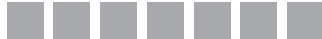 \\ Interview with Professor Jesper Strömbäck — University of Gothenhurg \\ DOI: 10.19195/1899-5101.10.1(18).9
}

The main subject of your research is the mediatization of politics. How do you assess the state of research on mediatization, especially that which is conducted in the region of Central and Eastern Europe?

Thus far I have not seen enough research on the mediatization of politics from the region of Central and Eastern Europe to allow any firm assessments. I do think however it is an interesting region for research on the mediatization of politics, not least considering the frequent attempts by some governments and other politicians in this region to politicize and use the media for political purposes. Poland and Hungary are just two examples. From a theoretical perspective, the politicization of the media should be understood as the opposite of the mediatization of politics, meaning that countries in which there are attempts to politicize the media might be particularly interesting cases for investigating the tensions between - and relative strengths of - media institutions versus political institutions and news media logic versus political logic.

Such cases are also a reminder that from a democratic perspective, the mediatization of politics is not necessarily something bad. It might be, if the process goes too far, but oftentimes the politicization of the media presents an even greater democratic problem.

Beyond this, my assessment is that research on the mediatization of politics has made great progress during the last decade, and that several important works have been published within the last few years (see, for example, Esser \& Strömbäck, 2014; Hjarvard, 2013; Lundby, 2014). To begin with, progress has been made with respect to how the mediatization of politics should be conceptualized. This includes how concepts-within-the-concept such as news media logic, political logic and media influence should be conceptualized within the framework of mediatization (see, for example, Strömbäck \& Esser, 2014). Although there are divergent views, and many still use mediatization as a kind of catch-all phrase, there seems to be growing consensus that the mediatization of politics is a multi-dimensional concept, where key dimensions are related to (a) the importance of the media as a source of political information, (b) the independence of the media from political institutions, 
(c) the degree to which media content is guided by news media logic as opposed to political logic, and (d) the degree to which political actors, organizations and institutions are guided by news media logic as opposed to political logic.

Progress has also been made with respect to how news media logic and political logic should be conceptualized. In that context, I think Esser's suggestion (2013) that news media logic should be conceptualized as being shaped by media professionalism, media commercialism and applied media technologies, while political logic is conceptualized as being shaped by polity, policy and policy, represents a particularly important contribution (see also Strömbäck \& Esser, 2014). My assessment is also that research increasingly has moved beyond overly simplified misconceptions that the mediatization of politics is a linear process of steadily increasing mediatization. Instead, there is growing recognition that the mediatization of politics has a dynamic and partly situational character, and that the degree of mediatization is contingent upon a number of factors on the system- or macrolevel as well as the meso- and micro-levels of analysis. The mediatization of politics is always a matter of degree, and the degree of mediatization varies both across and within countries. Finally, during recent years we have seen a number of empirical studies on the mediatization of politics, largely confirming but also adding nuance to the theoretical framework of mediatization (see, for example, Landerer, 2014; Sampert et al., 2014; Seethaler \& Melischek, 2014; Strömbäck \& Esser, 2015). This includes not only the mediatization of "party politics" in general, but also in specific policy domains such as foreign policy (Brommesson \& Ekengren, 2017), and extending to the mediatization of governmental agencies (see, for example, Fredriksson et al., 2015).

Having said this, much work remains. For example, there is a great need for more empirical research on the mediatization of politics along the third dimension (referring to the degree to which media content is guided by news media logic as opposed to political logic) as well as the fourth dimension (referring to the degree to which political actors, organizations and institutions are guided by news media logic as opposed to political logic). There is also a great need for comparative research, which is essential if we are to understand how the mediatization of politics is shaped by system-level factors. Related to this, we are only at the beginning of research exploring the contingency of the mediatization of politics, or the degree to which mediatization varies across political actors, organizations and institutions, as well as across different policy fields. Finally, there is a great need for research to help us understand how digital and social media are influencing and reshaping news media and news media logic and the relationship between media and politics.

Traditional media, due to their institutional and organizational character, are often the main subject of the analysis in the study of mediatization. However, it seems that the role of the Internet in this process is also significant. What is your opinion about this issue? 
I fully agree that the role of digital and social media is very important. They are important both in themselves and because network media logic (Klinger \& Svensson, 2015) differs from traditional news media logic. In some respects, digital and social media are also contributing to a de-institutionalization of the media, while in other respects, digital and social media are adapting to news media logic.

All this raises a host of questions related to the relationship between network media logic and news media logic, how digital and social media might reshape news media logic, and how digital and social media is empowering political actors, organizations and institutions by enabling them to bypass traditional news media. Important to remember though, is that traditional news media in most cases still constitute the most important source of political information, and that few political actors, organizations and institutions can afford to neglect traditional news media. At the same time, it is equally important to recognize that we are only in the beginning of the digital revolution.

All this calls for some caution when evaluating how digital and social media are influencing the relationship between media and politics in general and the mediatization of politics in particular. At this stage, I think it would be equally premature to claim that digital and social media does not influence the mediatization of politics as to claim that they change everything. Also important to remeber is that we humans have a tendency to overestimate the impact of new technologies in the short run, but underestimate and misunderstand the impact of new technologies in the longer run.

\section{How should online media be explored in the process of mediatization? What are the limits and the challenges of this type of research?}

It is hard to answer in general, since "online media" are so diverse. Does it refer to the online versions of traditional news media, to different kinds of alternative and online-only media, to social media, or to what? This multiplicity of different kinds of online media on digital platforms represents a challenge in itself. Another challenge is of course the liquid character of everything that is digital, meaning that content continuously might change due to human interventions as well as algorithms. Having said this, I think one promising venue of research would be to compare news media logic offline and offline, for example by comparing the extent to which news coverage online - in the online versions of traditional news media as well as in online-only media - is similar to or differs from news coverage offline. The same reasoning applies to political logic online and offline. Currently there is sometimes a presumption that news media logic and political logic online and offline differ from each other, but that is an empirical question. It is also worth noting that there is research suggesting that news media logic and political logic is quite similar online and offline (Hassler et al., 2014), but more research is needed here. It might also change across time. 
You have created the concept of the four phases of mediatization. You describe the degree of relationship between the media and political organizations and the influence of media on the actions of politicians. How do you assess the degree of adaptation of politicians to the media standards and their preparation to act in relations with the media today?

While the degree of adaptation to news media logic varies across countries as well as across political actors, organizations and institutions within countries, overall I would say that in contemporary democracies, most politicians are highly adapted to news media logic. They know fairly well how the news media function, and most politicians continuously take into consideration and think about how news media might react and cover them or their opponents if they suggest $\mathrm{a}, \mathrm{b}$ or $\mathrm{c}$ or if they stage or react to an event by $\mathrm{x}, \mathrm{y}$ or $\mathrm{z}$. Media considerations have become an ingrained part of political thinking, almost to the extent that politicians themselves might not always be aware of how much they take the media into consideration.

Important in the context is that the media influence encompasses not only what politicians say or do, but also what they decide not to say or not to do because they fear that it will lead to unwanted media reactions. While this "invisible aspect" of media influence and similar anticipatory effects are more difficult to investigate empirically, it might in fact be equally important as the kind of media influence that manifests itself in shaping what politicians actually say or do. In this context, I would also like to add that from the perspective of mediatization, media influence "refers to all activities and processes that are altered, shaped or structured by the media and the perceived need of individuals, organizations and social systems to communicate with or through the media" (Strömbäck \& Esser, 2014, p. 11). Media influence thus "both transcends and includes media effects" (Schulz, 2004, p. 90), and includes how media - indirectly or directly, unintentionally or intentionally - influences various political processes. That is also a kind of adaptation to the media, albeit of a different kind than when politicians deliberatively adapt to the news media in order to gain positive coverage or minimize negative coverage.

A significant part of political actors uses social media, where communication between the electorate and the politician is almost immediate/direct. Does the activity of politicians in social media mean that they become more independent of traditional media or the media in general in the context of creating messages to society and the opposition or not?

On one level of analysis, politicians' use of social media does make them more independent of traditional news media, but what matters most is (a) how many they reach by using social media versus being covered by traditional news media, (b) what groups of people they reach by social media versus traditional news media, and (c) for what purposes they use social media versus traditional news media. 
While social media is a great tool for reaching those who are highly interested in politics and who support you, it is generally speaking a less effective tool for reaching broader and more heterogeneous groups. Social media is thus more effective if the strategic goal is to mobilize supporters than if it is to reach and persuade the broader electorate. It might also be a useful tool if you want to reach and influence journalists, as part of the news management processes, as journalists often are avid users of social media.

Beyond this, I think anti-establishment and populist politicians have a greater use for social media than more traditional, established politicians. One reason is that populists often attack the news media as being part of the establishment, and using social media allows them to bypass traditional news media while catering to and spurring public distrust in traditional news media. Another reason is that social media, and Twitter in particular, lends itself to shorter, more affective, and more polarizing messages, and that fits better with how populists communicate than with traditional political communication. I think Donald Trump is a perfect example of this, but he is certainly not alone.

\section{In your latest book - Utan invandring stannar Sverige (Why Sweden Benefits from Immigration) you write about migration and its impact on Sweden. What were the most important results of your research?}

What I do in this book is basically to review research from various academic disciplines that deals with how host countries in general, and Sweden in particular, is affected by immigration. In contrast to the public debate, what I find is that research overwhelmingly shows that immigration benefits host countries. To mention just a few examples on how immigration benefits Sweden, research shows that immigration helps to slow down the ageing of the population; increase the share of the population that is of working age; increase the workforce both in terms of the number of people on the labor market and in terms of the qualifications and skills available at the labor market; spur creativity and innovation; increase the number of businesses and spur entrepreneurship; and increase exports, imports and foreign direct investments. There are also studies showing that immigration contributes to increasing efficiency and specialization on the labor market, as well as to higher productivity and economic growth. In some cases, the benefits are more immediate, while in other cases, they are more long-term, but the bottom line is that immigration benefits Sweden and other host countries. Historical research also shows that peaceful immigration, throughout the ages, has helped develop and strengthen host countries. It is thus not a new phenomenon, but it is also not a phenomenon that held true historically but not today.

Of course, all kinds of immigration are not alike. While labor migration more or less always benefits the host country, the situation is somewhat different when it comes to the immigration of refugees and their families. In the latter case, there is a fiscal cost associated with immigration. Three things are important to note though. First, the fiscal cost associated with this kind of immigration is quite lim- 
ited (in Sweden amounting to about 1-1.5 percent of BNP, which can be compared with the approximately 1 percent of BNP that is devoted to foreign aid). The key reason for why this kind of immigration is a fiscal cost is that it takes time until refugees and their families find employment and that the employment rate among these groups is lower than among other groups. Second and related, it is mainly a short-term cost. When refugees and their families get employment, they start contributing to the public finances. Third, fiscal effects and economic effects are not equivalent. Studies on the fiscal effects of immigration do not capture, for example, how immigration contributes to innovation, trade, business, or to productivity. Altogether this means that "the net fiscal impact of immigration could be negative while the economic benefit is simultaneously positive" (Nowrasteh, 2015, p. 63).

The bottom line is thus that Sweden is better off thanks to immigration. Given the research I have reviewed, I would say that it holds true for most other countries as well. It is important to recognize in this context is also that immigration and emigration is an integral part of open societies and globalization. While all countries can and do regulate immigration, the implication is that it is not possible to stop immigration and emigration while at the same time being an open society, reaping the benefits of globalization.

Do you think that the media's reporting of the migration crisis has been affected by politics or that politics has been affected by the media's reporting? Was the quality of journalism affected by concerns about which political forces might benefit from the reporting?

This is a very interesting, but ultimately empirical, question. In the absence of empirical research on this topic I am thus not sure, although my guess would be that politics has had a greater impact on the media coverage of the migration crisis than vice versa. Beyond that, I think that the coverage of the migration crisis in 2015 would be a very interesting case to study, in itself as well as to test different theories related to the relationship between media and politics. That includes mediatization, but also theories such as, for example, indexing and the official dominance model. Ideally, such a research endeavor would be comparative, as I am quite sure that there are important variations across countries, and as comparative research is necessary if we are to understand how macro-, meso- and micro-level factors interact and together contributes to shaping the media coverage.

\section{REFERENCES}

Brommesson, D., \& Ekengren, A-M. (2017). The Mediatization of Foreign Policy, Political DecisionMaking and Humanitarian Intervention. Basingstoke: Palgrave Macmillan.

Esser, F. (2013). Mediatization as a challenge: Media logic versus political logic. In: Kriesi, H., Lavenex, S., Esser, F., Matthes, J., Bühlmann, M., Bochlser, D. (eds.). Democracy in the Age of Globalization and Mediatization. Basingstoke: Palgrave Macmillan, pp. 155-176. 
Esser, F., Strömbäck, J. (eds.) (2014). Mediatization of Politics. Understanding the Transformation of Western Democracies. Basingstoke: Palgrave Macmillan.

Fredriksson, M., Schillemans, T., Pallas, J. (2015). Determinants of organizational mediatization: An analysis of the adaptation of Swedish government agencies to news media. Public Administration, 93 (4), 1049-1067.

Hassler, J., Maurer, M., Oschatz, C. (2014). Media logic and political logic online and offline. The case of climate change communication. Journalism Practice, 8 (3), pp. 326-341.

Hjarvard, S. (2013). The Mediatization of Culture and Society. London: Routledge.

Klinger, U., Svensson, J. (2015). The emergence of network media logic in political communication: A theoretical approach. New Media \& Society, 17 (5), pp. 1241-1257.

Landerer, N. (2014). Opposing the government but governing the audience? Exploring the differential mediatization of parliamentary actors in Switzerland. Journalism Studies, 15 (3), pp. 304320.

Lundby, K. (ed.) (2014). Mediatization of Communication. Berlin: Walter de Gruyter.

Nowrasteh, A. (2015). The Fiscal Impact of Immigration. In: Powell, B. (ed.). The Economic Consequences of Immigration. Market-Based Approaches, Social Science, and Public Policy. New York: Oxford University Press.

Sampert, S., Trimble, L., Wagner, A., Gerrits, B. (2014). Jumping the shark. Mediatization of Canadian party leadership contests, 1975-2012. Journalism Practice, 8 (3), pp. 279-294.

Schulz, W. (2004). Reconstructing Mediatization as an Analytical Concept. European Journal of Communication, 19 (1), pp. 87-101.

Seethaler, J., Melischek, G. (2014). Phases of Mediatization. Empirical Evidence from Austrian Election Campaigns since 1970. Journalism Practice, 8 (3), pp. 258-278.

Strömbäck, J. (2016). Utan invandring stannar Sverige. Stockholm: Volante.

Strömbäck, J., Esser, F. (2014). Mediatization of Politics: Towards a Theoretical Framework. In: Esser, F., Strömbäck, J. (eds.). Mediatization of Politics. Understanding the Transformation of Western Democracies. Basingstoke: Palgrave Macmillan, pp. 3-28.

Strömbäck, J., Esser, F. (eds.) (2015). Making Sense of Mediatized Politics. Theoretical and Empirical Perspectives. London: Routledge.

Jesper Strömbäck, Ph.D., is Professor in Journalism and Political Communication at the University of Gothenburg, Sweden, and associate editor of Political Communication. His research interests include the mediatization of politics, political news journalism, public opinion, media and campaign effects, political public relations, and comparative research. His recent books include Populist Political Communication in Europe (2016, edited together with Toril Aalberg, Frank Esser, Carsten Reinemann \& Claes de Vreese), Utan invandring stannar Sverige (2016) and Making Sense of Mediatized Politics (2016, co-edited with Frank Esser).

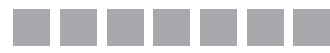

Prof. Jesper Strömbäck was interviewed online by Róża Smolak in November 2016. 